\title{
A legitimidade da graça: os impactos da tentativa de reforço da política sesmarial sobre as terras da Casa da Torre na capitania da Paraíba (século XVIII)
}

\author{
Carmen Margarida Oliveira Alveal* \\ Kleyson Bruno Chaves Barbosa**
}

\section{RESUMO}

Com o intuito de encontrar riquezas no vasto e desconhecido sertáo, a Coroa concedeu grandes extensóes de terras àqueles que se empenharam nessa missão. Foi nesse contexto que a Casa da Torre formou seu patrimônio, entre os séculos XVI e XVII. Mais tarde, entretanto, essa medida resultou em um grande entrave para a Coroa, que desembocou em conflitos por posses de terra durante o século XVIII. De um lado, observa-se a Coroa tentando legalizar o sistema sesmarial, por meio da expedição de várias ordens complementares. Do outro lado, observam-se os membros da Casa da Torre, entendendo-se como possuidores da terra de forma inquestionável, e os compradores das terras vendidas pela Casa da Torre, percebendo-se como verdadeiros proprietários da sesmaria. Portanto, este trabalho tem por objetivo demonstrar o processo de venda de sesmarias da Casa da Torre para colonos no sertáo do Piancó e os conflitos que os envolvem no tocante à posse e ao domínio de terras, por meio de cartas de sesmarias concedidas entre 1757-1765, documentos régios e outras fontes. Palavras-chave: Casa da Torre; sesmarias; capitania da Paraíba; América portuguesa, Ávila.

\section{ABSTRACT}

Aiming at finding riches in the vast and unknown backlands, the Portuguese Crown granted large portions of land to those who fulfilled this mission. It was in this context that the Casa da Torre amassed its assets between the $16^{\text {th }}$ and $17^{\text {th }}$ centuries. Later, though, the land grants became a problem for the Crown, resulting in many conflicts over land possession throughout the eighteenth century. On the one hand, the Crown was trying to regulate the sesmaria system, by issuing many complementary royal orders. On the other, members of

Artigo recebido em 18 de dezembro de 2013 e aprovado para publicação em 23 de fevereiro de 2014 .

DOI - http://dx.doi.org/10.1590/2237-101X016030003

* Doutora em História pela Johns Hopkins University (JHU), professora da Universidade Federal do Rio Grande do Norte (UFRN). Natal, RN, Brasil. E-mail: carmenalveal@uol.com.br.

** Bacharel em História pela Universidade Federal do Rio Grande do Norte (UFRN). Bolsista de Iniciação Científica - PROPESQ/UFRN. Natal, RN, Brasil.E-mail: k_b_chaves@yahoo.com.br. 
the Casa da Torre saw themselves as unquestionable owners of such land previously granted by the Crown. By the same token, those who purchased land from the Casa da Torre in the region also believed that they were valid holders of sesmarias. Through the registers of sesmarias granted between 1757-1765, official records and other primary sources, this essay intends to describe the process of land sales by the Casa da Torre to colonists in the Piancó backlands. It also reveals the involvement of this family in conflicts related to the possession and control of land.

Keywords: Casa da Torre; sesmarias; Captaincy of Paraíba; Portuguese America; Ávilas.

\section{Introdução}

Este artigo analisa a estratégia utilizada pela Casa da Torre em desfazer-se de parte de seu patrimônio à medida que aumentou o controle régio da Coroa portuguesa sobre as terras na sua possessão americana, especificamente na segunda metade do século XVIII, com base na análise das "sesmarias" possuídas pela Casa da Torre no sertão do Piancó, capitania da Paraíba. Procurar-se-á compreender como a Casa da Torre conseguiu um suposto patrimônio nessa região, e, principalmente, a consequente diminuição de terras nessa mesma localidade, verificada entre os anos de 1757 e 1776, decorrentes de conflitos com moradores da área citada. Para isso, é preciso que se entenda a dinâmica do sistema sesmarial, e as estratégias de utilização deste sistema pelos moradores e pelos membros da Casa da Torre, observáveis por meio de cartas de sesmarias e ordens régias expedidas referentes à legislação de sesmarias. Ao analisar esses conflitos ocorridos, espera-se demonstrar as relaçóes de poder perceptíveis envolvendo os dois lados no conflito, e como o ordenamento jurídico sobre o sistema sesmarial, ao longo dos tempos, na América portuguesa, passou a amparar os moradores ${ }^{1} \mathrm{em}$ detrimento dos grandes sesmeiros, ${ }^{2}$ que possuíam extensas terras, como era o caso da Casa da Torre. Isto era resultado de uma tentativa de controle régio mais efetivo por parte da Coroa, e representava uma busca da diminuiçáo de poder desses grandes senhores de terra, que formaram seu patrimônio no início da colonizaçáo no Brasil.

Por meio de fontes como cartas de concessão de sesmarias, observa-se que há uma maior concentração de pedidos das mesmas na regiáo mais afastada do litoral na capitania da Paraíba, durante o século XVIII. Este foi um século de consolidação, por parte daqueles homens que estavam envolvidos com o projeto de povoamento liderado pelos portugueses, do

\footnotetext{
${ }^{1} \mathrm{O}$ termo refere-se àquelas pessoas que estavam fixadas na América portuguesa, por meio da relação que possuíam com a terra.

${ }^{2} \mathrm{O}$ termo refere-se àqueles homens ou famílias que por meio do recebimento de sesmarias possuíam uma quantidade extensa de terras (mais de 10 léguas) se comparado aos outros sesmeiros no período colonial, destacando-se, por exemplo, os Ávila e os Guedes de Brito.
} 
seu domínio nos sertóes das capitanias do Norte, que vinha sendo realizado desde o século anterior, na luta contra o gentio e na integração do mesmo à sociedade colonial. Entre os anos de 1757 a 1776, por exemplo, foram concedidas pelo menos 279 sesmarias na capitania da Paraíba. ${ }^{3}$ Deste total, destaca-se um conjunto de 31 sesmarias, a maioria delas localizadas na região do Piancó. A atenção volta-se para a constante referência que o conteúdo dessas cartas fazia à Casa da Torre. ${ }^{4}$ Os requerentes dessas sesmarias concedidas alegavam que a área em que solicitavam suas sesmarias havia sido da Casa da Torre, ou, entáo, que haviam comprado dessa família as tais terras, sem ter recebido um título de sesmaria que comprovasse a sua efetiva posse, a não ser "uma simples escritura, sem mais outro título" 5 Outros declaravam ser rendeiros/posseiros da mesma Casa da Torre, e, alguns mais ousados, denunciavam a Casa da Torre como possuidora indevida das tais terras, que se sentia senhora intrusamente de extensas terras, nas palavras dos próprios suplicantes.

Aliás, a presença da Casa da Torre nos territórios da capitania da Paraíba é algo notório nas próprias cartas de doação de sesmaria em períodos anteriores. Em carta concedida, por exemplo, ao comissário Teodósio Alves de Figueiredo, no ano de 1739, o requerente informou que nos pontos cardeais leste e oeste da sesmaria solicitada as confrontaçóes correspondiam a terras da Casa da Torre. ${ }^{6}$ Já a sesmaria concedida ao capitão-mor Francisco de Oliveira Ledo e ao licenciado Joáo dos Santos, no ano de 1752, citou a mesma Casa da Torre como confrontação dessa sesmaria nos pontos cardeais norte e oeste. ${ }^{7}$ Outras cartas, em períodos anteriores ou posteriores, comprovam a presença da Casa da Torre na capitania da Paraíba, ora citando a própria Casa da Torre como confrontante das sesmarias solicitadas, ora algum membro da família Ávila. ${ }^{8}$ Além dessas cartas, as próprias cartas exploradas neste artigo correspondem a concessóes de sesmarias nas tais terras ditas pertencentes da Casa da Torre.

Márcia Motta argumentou que "a história do patrimônio dos Garcia do século XVIII parece anunciar um crescente questionamento sobre os limites territoriais da família e sobre

\footnotetext{
${ }^{3}$ Informação obtida na Plataforma SILB. A Plataforma SILB (Sesmarias do Império Luso-Brasileiro) é uma base de dados que pretende disponibilizar on-line as informaçôes das sesmarias concedidas pela Coroa portuguesa no mundo atlântico. Acesso em: 4 set. 2013. Disponível em: <http://www.silb.cchla.ufrn.br>. Das 1.146 sesmarias concedidas na capitania da Paraíba, registradas na Plataforma SILB, 1.019 foram concedidas no século XVIII, correspondendo a $88,9 \%$ das concessóes realizadas.

${ }^{4}$ A Casa da Torre pertencia à família dos Ávila, oriundos da Bahia. Possuía um dos maiores patrimônios no período colonial, com extensas terras na atual região do Nordeste brasileiro.

${ }^{5}$ Expressão que aparece nos textos das cartas.

${ }^{6}$ CARTA de sesmaria doada a Teodósio Alves de Figueiredo, em 1o de outubro de 1739. Plataforma SILB - PB 0267.

${ }^{7}$ CARTA de sesmaria doada a Francisco de Oliveira Ledo e Joao dos Santos, em 4 de outubro de 1752. Plataforma SILB - PB 0407.

${ }^{8}$ Outras cartas de sesmaria que atestam, por exemplo, a presença da Casa da Torre na capitania da Paraíba, como confrontaçóes das próprias sesmarias: PB 0326, PB 0409, PB 0461 e PB 0508. Para consultar mais cartas, acesse $<$ http://www.silb.cchla.ufrn.br $>$. Plataforma SILB.
} 
as distintas percepçôes a respeito do direito à terra", ${ }^{9}$ e isto ficará evidente no decorrer deste trabalho. Percebe-se que, na segunda metade do século XVIII, ocorreu um movimento que atesta a diminuição de terras da Casa da Torre na capitania da Paraíba. Esse processo confunde-se com a própria dinâmica do sistema sesmarial e a sua transformação/adaptação na América portuguesa durante os três séculos de seu funcionamento. $\mathrm{O}$ entendimento desse processo de perda de terras é possibilitado também pela própria mentalidade dos sesmeiros que receberam terras consideradas, antes da concessão, como pertencentes da Casa da Torre, utilizando a legislação sesmarial a seu favor, ou seja, compraram terras por meio de escrituras, de suposta titularidade da Casa da Torre, antes da Ordem Régia de 1753, e posteriormente solicitaram as cartas de sesmarias referentes a essas terras. ${ }^{10}$ Portanto, apesar de estarem de posse de escrituras de compra das terras, havia o medo dos moradores diante do risco eminente da perda de terras ditas por eles como suas. Essa ideia era baseada na prática do cultivo e no costume, associado à própria crença deles sobre a propriedade no período colonial, e contribui para clarificar o processo aqui discutido.

\section{A Casa da Torre e a ocupação do sertão da capitania da Paraíba}

O primeiro Ávila, Garcia d'Ávila, chegou ao Estado do Brasil em 1549, acompanhando a missão de Tomé de Sousa. ${ }^{11}$ Apesar do desconhecimento de sua origem, especula-se que Garcia d'Ávila possuísse alguma relação de parentesco com este governante. Sabe-se que a família dos Ávila formou um grande patrimônio, que, segundo Ângelo Pessoa, correspondia a terras que compreendiam os seguintes estados da atual região Nordeste: Bahia, Sergipe, Alagoas, Pernambuco, Paraíba, Ceará e Piauí. ${ }^{12}$ Conforme Moniz Bandeira, a Casa da Torre, em três geraçóes, após a morte de Garcia d’Ávila em 1609, aumentara seu domínio de tal forma que era senhora de grande parte dos sertôes da Bahia e de Sergipe, e, em fins do século XVII, estendera esse domínio a quase todo vale do rio São Francisco, ocupando terras em Pernambuco, Piauí e Paraíba, e inclusive, no Rio Grande do Norte. ${ }^{13}$

\footnotetext{
${ }^{9}$ MOTTA, Márcia Maria Menendes. Tierra, Poder y Privilegio. Los mayorazgos coloniales y el ejemplo de la Casa da Torre (siglo XVIII). In: ÁLVAREZ, Maria José Pérez; GARCÍA, Alfredo Martín (Org.). Campos y campesinos en la España Moderna. 1. ed., v. 1. León: Fundación Espanôla de História Moderna, 2012. p. 1.422 .

${ }^{10}$ Conforme Paolo Grossi, a ideia de propriedade é plural. Embora os moradores tivessem o título de escritura de compra e venda, e ainda cultivassem a área, havia o receio por não terem o título de sesmaria. GROSSI, Paolo. A propriedade e as propriedades na oficina do historiador. In: História da propriedade e outros ensaios. Rio de Janeiro: Renovar, 2006

${ }^{11}$ PESSOA, Ângelo Emílio da Silva. As ruinas da tradição: a Casa da Torre de Garcia D’Ávila - família e propriedade no Nordeste colonial. Tese (Doutorado em História) — Faculdade de Filosofia, Letras e Ciências Humanas, Universidade de São Paulo, São Paulo, 2003. p. 74.

${ }^{12}$ Ibid., p. 76.

${ }^{13}$ BANDEIRA, Luiz Alberto Moniz. O feudo - A Casa da Torre de Garcia d'Ávila: da conquista dos sertôes à independência do Brasil. 2. ed. revista e ampliada. cap. VI. Rio de Janeiro: Civilização Brasileira, 2007. p. 236.
} 
Importantes famílias criaram seus patrimônios nos séculos XVI e XVII devido ao fato de terem sido realizadas grandes concessóes de terras pela Coroa àqueles que desbravassem o sertão em busca de riquezas. Em meados do século XVII, com pequena introdução ao interior, grandes extensóes de terras eram concedidas sem maiores problemas, visto as possibilidades econômicas de sua exploração. ${ }^{14}$ Dessa forma, a Casa da Torre formou seu patrimônio por meio da concessão de sesmarias, obtidas pelos serviços prestados por membros da família à Coroa na contribuição para o desbravamento do sertão, travando lutas contra indígenas, o que lhes renderam também a conquista de cargos políticos e militares, tornando-se uma das famílias mais poderosas.

A conquista dos sertôes liga-se com a própria trajetória da Casa da Torre. A ocupação do sertão da capitania da Paraíba teria primeiramente a presença dos Ávila. Moniz Bandeira afirmou que, entre 1662 e 1663 , os sertôes do atual Piauí e a região extrema ocidental da Paraíba haviam sidos penetrados pela Casa da Torre. ${ }^{15}$ Bandeira baseou-se em afirmação realizada por Basílio de Magalhães, que, por sua vez, baseou-se em uma carta de sesmaria descoberta por Pereira da Costa e reproduzida no seu livro Chronologia histórica do Estado do Piauhy ${ }^{16}$ Essa carta havia sido concedida pelo governador de Pernambuco, Francisco de Castro Moraes, em 03 de janeiro de 1705, para 14 pessoas, incluindo Dona Jeronyma Cardim Fróes, viúva de Domingos Jorge Velho. Segundo a mesma carta, a sesmaria iniciava-se na nascente do rio "Poty" (ou Potengi) ao rio "Parnahyba", no Piauí, correspondendo a uma extensa data de sesmaria. Os requerentes alegaram que conjuntamente com Domingos Jorge Velho haviam povoado o rio "Potingh" e o rio "Parnahyba", enfrentando os tapuias bravos, e tendo diversas criaçóes há cerca de 24 ou 25 anos. Informaram ainda que povoaram "todo o Piauhy e Canindé em companhia da Casa da Torre de Garcia d'Ávila" além das fronteiras do Maranhão, quando Domingos Jorge Velho foi chamado para combater os negros rebelados dos Palmares, por volta do ano de 1687. Portanto, para Pereira da Costa, seria nos anos de 1662 ou 1663 que Domingos Jorge Velho teria começado a desbravar o sertão do Piauí, considerando a literalidade do texto da carta de sesmaria de 1705 , pois se em 1687 os requerentes habitavam há 24 ou 25 anos, lutando contra índios e povoando o Piauí, conjuntamente com a Casa da Torre, tais exploraçóes datariam por volta de 1662 ou 1663.

Baseando-se no historiador paraibano Wilson Seixas, Bandeira enfatizou que a Casa da Torre foi "a primeira a ocupar as terras de Piancó, Piranhas e rio do Peixe, a partir de 1664, quando transpôs o rio S. Francisco, subiu o Pajeú e daí se comunicou com a bacia

${ }^{14}$ ALVEAL, Carmen Margarida Oliveira. Converting land into property in the Portuguese Atlantic World, 16 $6^{\text {th }}-18^{\text {th }}$ century. 2007. 366 f. Dissertação (Doutorado em Filosofia) - Johns Hopkins University, Baltimore, 2007. p. 276.

${ }^{15}$ BANDEIRA, Luiz Alberto Moniz, op. cit., cap. V. p. 194-195.

${ }^{16} \mathrm{O}$ autor informou que a carta de sesmaria foi extraída integralmente do livro de registro existente no arquivo da Secretaria do Governo de Pernambuco. COSTA, F. A. Pereira da. Chronologia histórica do Estado do Piaui. 1. ed. Recife: Typographia do Jornal do Recife, 1909. p. 6-7, 21-23. 
do Piranhas". ${ }^{17}$ Celso Mariz, jornalista paraibano, ao abordar a expansão territorial na capitania da Paraíba, informou que, primeiramente, a ocupação ocorreu no litoral, e após a retirada dos holandeses da capitania da Paraíba, as exploraçôes no interior recomeçaram. Teria sido nesse período, pós-retirada holandesa, que, segundo Mariz, os baianos e paulistas $^{18}$ apareceram nos sertôes da região. O autor, portanto, citou Domingos Jorge Velho, por parte dos paulistas, e a Casa da Torre, por parte dos baianos, que teriam estado nos sertóes da capitania da Paraíba. ${ }^{19}$ Rodrigo Ceballos também confirmou a presença de Domingos Jorge Velho, por volta de 1660, a serviço do governador de Pernambuco, em compreensôes do Piauí, Ceará e Paraíba, onde teria fundado o arraial de Piranhas, antes mesmo da chegada de Oliveira Ledo, outra família vinda da Bahia. Ceballos fez referência à Casa da Torre como responsável pela conquista do sertão da atual regiáo Nordeste. Aliás, ressaltou que essas conquistas da Casa da Torre teriam sido realizadas em parceria com Domingos Jorge Velho e Domingos Afonso Sertão. As terras de Piranhas, na capitania da Paraíba, teriam sido ocupadas para si pelos Ávila, juntamente com outros sertanistas, após intensas lutas contra indígenas. ${ }^{20}$

A geógrafa Emília de Rodat Fernandes Moreira, abordando o processo de ocupaçáo do espaço agrário atual paraibano, ressaltou a importância da pecuária, tanto bovina quanto equina, como propulsora para a conquista do sertão, não somente na capitania da Paraíba, mas no território da América portuguesa. ${ }^{21}$ Esta era uma atividade econômica de vital importância para o patrimônio da Casa da Torre, e que será exemplificado posteriormente neste trabalho. Segundo Moreira, foi da capitania da Bahia que a criação de gado teria sido irradiada em direção ao norte, seguindo o curso do rio São Francisco, passando por Pernambuco e alcançando Piauí e Maranhão. ${ }^{22}$ A Casa da Torre, que possuía uma das maiores terras do período colonial, participaria diretamente dessa conquista e interiorização do gado bovino e equino nos sertôes, travando lutas com indígenas, colaborando para a expansão portuguesa no Novo Mundo. Explica-se, assim, a importância e o acúmulo do seu cabedal

\footnotetext{
${ }^{17}$ Moniz Bandeira baseou-se em: Wilson Seixas. Pesquisas para a história do sertáo da Paraíba. Revista do Instituto Histórico e Geográfico Paraibano, João Pessoa, no 21, 1975, p. 65. Este, por sua vez, não citou fonte documental que confirme a sua argumentação. Wilson Seixas ainda ressaltou, sendo citado por Moniz Bandeira, que foi nesse período que a Casa da Torre devassou os campos de várias tribos indígenas, estabelecendo uma rede de integração territorial. In: BANDEIRA, Luiz Alberto Moniz, op. cit., cap. 5. p. 195-196.

${ }^{18}$ Os termos paulista e baiano referenciados pelo próprio autor são no sentido de localizar a procedência geográfica dos grupos que ocuparam o sertão do Piancó, e não com o intuito de constatar algum pertencimento e identidade a esses mesmos locais.

${ }^{19}$ MARIZ, Celso. Expansão territorial — I Primeiras aldeias mestiças - Os paulistas e baianos no interior. In: MARIZ, Celso. Apanhados Históricos da Paraíba. 2. ed. João Pessoa: Editora Universitária UFPB, 1980. ${ }^{20}$ CEBALLOS, Rodrigo. Veredas sertanejas da Parahiba do Norte: a formação das redes sociais, políticas e econômicas no arraial de Piranhas (século XVIII). Anais do XXVI Simpósio Nacional de História ANPUH, São Paulo, julho 2011. p. 2.

${ }^{21}$ MOREIRA, Emília de Rodat Fernandes. Processo de ocupação do espaço agrário paraibano. Textos UFPB/ NDIHR no 24 set./1990. p. 6.

${ }^{22}$ Idem.
} 
durante os dois primeiros séculos da colônia e a sua pretensão de se considerar senhora de terras de quase toda atual regiáo do Nordeste, contrariando a Coroa e o próprio sistema sesmarial que se tornou restritivo em fins do século XVII.

Portanto, a parte mais ocidental da Paraíba teria sido visitada, primeiramente, por estes sertanistas, na ocupação em nome da Coroa portuguesa. O controle efetivo dessa região, entretanto, deveu-se a outra família, os Oliveira Ledo. Provavelmente, alianças entre os Oliveira Ledo, Ávila e outros sertanistas teriam contribuído para o tal período de sossego, que Mariz descreveu ao abordar o século XVIII na capitania da Paraíba. Segundo Mariz, em 1685 foi organizada a bandeira de Teodósio de Oliveira Ledo, fundamental para o povoamento e a conquista do sertão paraibano, marcando o início da busca dos sertóes além Borborema, chegando às águas do Piancó e Piranhas. ${ }^{23}$ Todavia, o autor não apresentou documentação comprovando a bandeira organizada por Teodósio de Oliveira Ledo. Mariz supôs que, naquela região, os chamados paulistas e baianos já se encontravam, embora tenha ressaltado que os parentes de Teodósio dominaram-na.

Acredita-se haver alguma ligação entre a família Oliveira Ledo e os Ávila. Em trabalho defendido em 2012 por Renata Costa, a autora levantou a hipótese de que a família dos Oliveira Ledo era, provavelmente, proveniente de Portugal, da regiáo do Douro e do Minho. ${ }^{24}$ Já na tese de Ângelo Pessoa, ao formular a possível relação de parentesco do primeiro Garcia d’Ávila com Tomé de Sousa, o autor informou que este último era de Sáo Pedro de Rates, no Minho, e provavelmente seria a terra natal também de Garcia d'Ávila. ${ }^{25}$ Observa-se, assim, uma hipotética ligação entre as duas famílias, consideradas pioneiras na conquista do sertão da Paraíba.

Outros pontos reforçam essa provável ligação entre essas famílias na conquista e domínio dessa região. Pedro Calmon, no capítulo "Os Procuradores", incorporado na segunda edição do seu trabalho sobre a Casa da Torre, apresentou um dos meios pelos quais a família Ávila conseguia impor e controlar o seu domínio em territórios táo vastos. Segundo Calmon, "para governar tão largas terras usaram os senhores da Torre o sistema de se associarem aos régulos ou capitães que nomeavam procuradores, dando-lhes autoridade, apoio e força. Em troca, davam-lhes sujeição, tributo e homenagem". ${ }^{26}$ Este autor baseou-se nos escritos de João da Maia da Gama, governador da Paraíba entre 1708 e 1717, e governador do Maranhão, entre 1722 e 1728, que em seus diários de viagens pelo sertão, em

\footnotetext{
${ }^{23}$ MARIZ, Celso. Expansão territorial — II A bandeira de Teodósio — Confederação e Guerra dos Tapuias - Conquista do Piancó - Fundaçóes do interior - Últimas entradas, op. cit.

${ }^{24}$ A autora baseou-se na carta do ouvidor geral da Paraíba, Manuel da Fonseca e Silva, ao rei, D. João V, 03.11.1724. AHU-PB, PA, Cx. 5, Doc. 426. In: COSTA, Renata Assunçáo da. Uma nova conquista: A família Oliveira Ledo e o processo de ocupação espacial do sertáo do Piancó (1663-1730). Monografia (Graduação em História) - Departamento de História, Universidade Federal do Rio Grande do Norte, Natal, 2012.

${ }^{25}$ PESSOA, Ângelo Emílio da Silva, op. cit., p. 53.

${ }^{26}$ CALMON, Pedro. Os Procuradores. In: História da Casa da Torre - Uma dinastia de pioneiros. 2. ed. aumentada. cap. VIII. Rio de Janeiro: Livraria José Olympio Editora, 1958. p. 127.
} 
1728, escreveu que havia sido obrigado a "notificar o Capitão mor Theodosio de Oliveira Ledo e o coronel Manuel de Araújo de Carvalho e Sargento mor João de Miranda todos Procuradores da Caza da Torre...”. ${ }^{27}$ Ainda segundo João da Maia da Gama, referindo-se aos procuradores da Casa da Torre, descrevia-os como "os mais poderosos, mais facinoros, e mais temidos que athé hoje em dia uzarão e uzão destas violências com a maior vexação forssa, violência, e injustissa feita aos vaçallos de V. Magestade.... ${ }^{28}$ Para Renata Costa, "a figura de Teodósio de Oliveira Ledo [...] era bastante respeitada. Teodósio era visto como um sujeito de grande valor, dotado de práticas militares e com experiência em realizar guerra contra os 'bárbaros". ${ }^{29} \mathrm{O}$ título de capitão-mor das Piranhas e Piancó foi concedido pela Coroa portuguesa à família Oliveira Ledo, ficando sob seu domínio por muitos anos. Assim, percebe-se como a Casa da Torre, por meio de alianças com pessoas influentes localmente, conseguia preservar o seu domínio, criando redes que contribuíam para fortalecer ainda mais sua presença no sertáo da capitania da Paraíba. A Casa da Torre ligou-se, portanto, a uma família que possuía prestígio e poder, práticas militares e experiência em guerra contra o gentio, que era a família Oliveira Ledo. A presença da violência é algo que não se descarta, ainda mais caso se pense em regióes tão afastadas do controle da Coroa. Este era um dos meios utilizados para que o poder desses senhores fosse legitimado e respeitado pelos moradores localizados nessas regióes sertanejas.

Segundo Renata Costa, a família Oliveira Ledo foi fundamental para a conquista do ocidente da capitania da Paraíba, mesmo sem saber quem teria chegado primeiro nessa região (a Casa da Torre ou os próprios Oliveira Ledo). Sua afirmação baseou-se no argumento que os Oliveira Ledo souberam relacionar-se com o poder central, por meio de subsídios para a ocupação territorial, como também teriam estabelecido alianças com grupos indígenas, possibilitando sua instalação no sertão. ${ }^{30}$ Ainda segundo a autora, baseando-se em Irineu Pinto, a família Oliveira Ledo, de Portugal, teria vindo inicialmente à Bahia, proporcionando uma relação direta dos membros da família com o governador geral do Brasil, e, assim, estreitando laços com a Coroa portuguesa. ${ }^{31}$ Sabe-se que a Casa da Torre possuía a sua sede na Bahia, em Tatuapara, sendo influente também e ocupando cargos políticos e militares na administração colonial. Portanto, podemos formular uma hipótese na qual a conquista do sertáo em análise teria ocorrido por meio de alianças realizadas entre a família dos Ávila e dos Oliveira Ledo, além da presença de Domingos Jorge Velho. Teriam sido criadas redes que beneficiavam ambos os envolvidos na ocupação das regiōes sertanejas. Precisa-se, toda-

${ }^{27}$ MARTINS, F. A. de Oliveira. Um herói esquecido: João da Maia da Gama. Vol. II. Lisboa: Coleção Pelo Império, 1944. p. 26.

${ }^{28}$ Ibid., p. 27.

${ }^{29}$ COSTA, Renata Assunção da, op. cit., cap. 3. Baseia-se em trechos de Wilson Seixas, transcrita no sítio eletrônico do Instituto Histórico Geográfico da Paraíba. Disponível em: <http://www.ihgp.net/pb500.htm>. ${ }^{30}$ Ibid., cap. 1, p. 21-23.

${ }^{31}$ Ibid., cap. 1. Baseia-se em PINTO, Irineu Ferreira. Datas e notas para a História da Paraíba. v. 1. João Pessoa: Editora Universitária, UFPB, 1977. 
A LEGITIMIDADE DA GRAÇA: OS IMPACTOS DA TENTATIVA DE REFORÇO DA POLÍTICA SESMARIAL SOBRE AS TERRAS DA CASA DA TORRe na CAPITANIA Da PARAÍba (sÉCUlo XVIII)

Carmen Margarida Oliveira Alveal e Kleyson Bruno Chaves Barbosa

via, de um estudo mais apurado que venha comprovar como essas relaçóes ocorriam entre as tais famílias.

Para Ângelo Pessoa, os procuradores da Casa da Torre eram grandes sócios da Casa. O lucro que obtinham nessas relaçóes era a possibilidade de partilharem de grandes sesmarias, o que, em troca, possibilitava para a Casa da Torre que os foros cobrados por pequenos posseiros em terras consideradas suas fossem arrecadadas nos remotos sertóes, utilizando a violência como costume. ${ }^{32}$ A notável influência da Casa da Torre, por meio das suas extensas sesmarias concedidas no século XVI, pode ser sentida, portanto, quando observamos a família Oliveira Ledo agindo em seu favor no sertão da capitania da Paraíba.

Distantes, os membros da Casa da Torre mantinham o seu controle sobre a regiáo do Piancó, Piranhas e rio do Peixe, na parte mais ocidental da capitania da Paraíba, por meio dos sítios que arrendava, tendo como representantes a família Oliveira Ledo, que, segundo trabalho já mencionado de Renata Costa, na conquista de territórios, obteve, além de um enorme patrimônio com extensas sesmarias, um prestígio local. ${ }^{33}$ Entretanto, essa ligação inicial apresentou ruptura posteriormente, e a própria dinâmica do sistema sesmarial começou a ser modificada no avançar dos séculos no período colonial. Observa-se uma diminuição das terras por parte da Casa da Torre na capitania da Paraíba, a partir da segunda metade do século XVIII.

\section{Sistema sesmarial e diminuição do patrimônio da Casa da Torre}

Conforme já explicitado na introdução deste trabalho, entre o período de 1757 a 1776, foram concedidas pelo menos 31 sesmarias, ${ }^{34}$ que, se sabe, pertenciam anteriormente ao patrimônio da Casa da Torre no sertão da capitania da Paraíba. Considerando a dimensão da sesmaria mais usual concedida na época estudada, de três léguas de comprimento por uma légua de largura, chega-se ao cálculo de 93 léguas quadradas ${ }^{35}$ subtraídas do patrimônio da Casa da Torre, em um período curto e sucessivo, como se pode constatar no quadro 1. Em menos de vinte anos, o patrimônio da Casa da Torre foi reduzido consideravelmente.

\footnotetext{
${ }^{32}$ PESSOA, Ângelo Emílio da Silva, op. cit., p. 173.

${ }^{33}$ COSTA, Renata Assunção da, op. cit., cap. 1, p. 23. A autora no momento é mestranda, e procura entender as relaçóes entre os Ávilas e os Oliveira Ledo na capitania da Paraíba, durante o século XVIII, podendo, portanto, contribuir para um maior esclarecimento sobre as questóes aqui elucidadas e discutidas.

${ }^{34}$ Plataforma SILB — PB 0451, PB 0452, PB 0463, PB 0469, PB 0491, PB 0493, PB 0494, PB 0495, PB 0497, PB 0502, PB 0504, PB 0505, PB 0513, PB 0514, PB 0515, PB 0518, PB 0525, PB 0528, PB 0537, PB 0548, PB 0554, PB 0559, PB 0583, PB 0585, PB 0614, PB 0622, PB 0624, PB 0626, PB 0653, PB 0715 e PB 0716 .

${ }^{35}$ Costa Porto ressaltou a dificuldade de definir o que seria a légua, possuindo modalidades como ordinárias, quadradas, em quadro, "conceitos nem sempre muito bem claros". In: PORTO, Costa. Estudo sobre o sistema sesmarial. Recife: Imprensa Universitária, 1965. p. 92.
} 
A LEGITIMIDADE DA GRAÇA: OS IMPACTOS DA TENTATIVA DE REFORÇO DA POLÍTICA SESMARIAL SOBRE AS TERRAS DA CASA DA TORRe na CAPITANIA Da PARAÍba (sÉCUlo XVIII)

Carmen Margarida Oliveira Alveal e Kleyson Bruno Chaves Barbosa

Entretanto, uma perda de extensas áreas como essas não seria percebida passivamente pelos membros da Casa da Torre, que obtinham recursos, principalmente, por meio das suas fazendas de currais. Todavia, passar-se-á, inicialmente, a observar o que há no conteúdo dessas 31 cartas, e o que os requerentes argumentaram em seu favor para conseguir os títulos.

\section{Quadro 1}

Sesmarias concedidas em terras ditas pertencentes à Casa da Torre na capitania da Paraíba entre os anos de 1757-1776

\begin{tabular}{|c|c|c|c|c|c|c|c|c|c|c|c|}
\hline Sesmarias & 1757 & 1758 & 1759 & 1760 & 1761 & 1762 & 1764 & 1765 & 1768 & 1776 & Total \\
\hline Quantidade & 3 & 1 & 12 & 3 & 3 & 2 & 1 & 3 & 1 & 2 & 31 \\
\hline
\end{tabular}

Fonte: Elaborado pelos próprios autores, baseando-se nas cartas de sesmarias contidas na Plataforma SILB.

Deste total de concessóes, 26 requerentes de 26 sesmarias alegaram que haviam comprado as terras da Casa da Torre; dois alegaram que haviam pago rendas a essa mesma Casa; um informou que possuía as terras pagando foro; um havia arrematado; e outro não informou o meio pelo qual havia obtido as terras requeridas, mas assinalou que as terras eram pertencentes à Casa da Torre. Joanna Maia Martins alegou, por exemplo, que, "o seu defunto marido comprou à casa da Torre um sitio de terras de crear gados no sertão do Piancó, do qual não tinham os vendedores títulos mais do que a sua antiga e quasi immemorial posse", o qual recebeu a requerente por sesmaria em 28 de abril de $1757 .{ }^{36}$ As justificativas por parte dos requerentes tornam-se constantes, enfatizando-se a questáo de eles terem, em sua maioria, recebidos apenas uma simples escritura de venda da Casa da Torre, sem qualquer outro título que comprovasse o domínio e posse das terras requeridas por sesmaria. Percebe-se, então, a importância atribuída ao título de sesmaria para assegurar a posse desses cultivadores, mesmo apesar de terem recebido uma escritura de venda de uma família considerada poderosa. Para se sentirem seguros, esses povoadores requereram a sesmaria, a fim de estarem de posse do "justo" título. O objetivo, com isso, era estarem legalizados com a própria ordem emana-

\footnotetext{
${ }^{36}$ CARTA de sesmaria doada a Joanna Maia Martins, em 28 de abril de 1757. Plataforma SILB — PB 0452. De acordo com a escritura de venda, o marido de Joanna, Pedro Velho Barreto, havia comprado por 500 mil réis, em 1740, do procurador da Casa da Torre, João de Miranda, as terras que a requerente iria requerer em 1757, enquanto viúva. LIVRO de Notas de Pombal (século XVIII). Doc. 39, liv. 1738-1740, fl. 45 a fl. $46 v$. In: CEBALLOS, Rodrigo; LÔBO, Isamarc Gonçalves. Procuraçôes, líbelos e escrivães - fontes manuscritas setecentistas do sertáo paraibano. Cajazeiras: EDUFCG, 2012. 1 CD-ROM. Encontrou-se ainda outra escritura de venda de uma terra solicitada por Severina Vieira, que também corresponde a uma das 31 sesmarias trabalhadas neste artigo: PB 04447, doada em 20 de março de 1757. A requerente era viúva do capitão Luiz Mendes de Sá, que havia comprado o Sítio Várzea do Ovo no ano de 1742, por meio do capitáo-mor João de Miranda, procurador dos membros da Casa da Torre. Consta na escritura de venda que o procurador e vendedor, capitáo-mor João de Miranda, "em nome dos ditos seos constituintes [membros da Casa da Torre] vendia como de facto logo vendeo ao dito comprador Luis Mendes de Sá por presso e quantia de oitocentos e sincoenta mil reis que do dito comprador tem recebido" o sítio denominado de Varzea do Ovo. In: LIVRO de Notas de Pombal — século XVIII. Doc. 84, liv. 1740-1742, fl. numeração ilegível a fl. 84v.
} 
da do reino. Por outro lado, percebe-se, no discurso dos requerentes, a denúncia indireta de que aqueles que venderam tais terras, a Casa da Torre, encontravam-se sem o tal título, por não terem entregado a esses compradores.

Alguns eram mais diretos no texto de suas justificativas, denunciando que a Casa da Torre assenhoreava-se de terras sem estarem legalizadas de acordo com o sistema sesmarial. ${ }^{37}$ Por conseguinte, o alferes Bartolomeu Pereira Dantas recebeu uma sesmaria, no ano de 1760, o qual relatou que havia pagado renda à Casa da Torre, cultivando a terra há mais de 30 anos, quando no ano de 1753 foi lançado fora pelo capitáo-mor Francisco de Oliveira Ledo, sem autoridade judicial, a náo ser com uma carta de sesmaria, ${ }^{38}$ conseguida de forma ilícita. ${ }^{39}$ Mais uma vez, observa-se a família Oliveira Ledo, influente na regiáo, e, que deve ter utilizado da violência, para impor seus interesses. $\mathrm{O}$ mesmo requerente chegou a acusar o governante da capitania da Paraíba, Antônio Borges da Fonseca, ${ }^{40}$ de ter concedido ilicitamente a tal sesmaria para Ledo. Portanto, o requerente acusou o capitão-mor Francisco de Oliveira Ledo de ocupar as terras indevidamente, assim como argumentou que as terras solicitadas por ele "menos seria da casa da Torre por esta não ter titulo algum de sesmaria mais que uma intrusa posse nesta ribeira do rio do Peixe". ${ }^{41}$ Interessante é que, apesar de todos esses argumentos e da concessão realizada, um ano e meio depois, outra carta de concessão foi deferida, na qual o requerente, Timóteo Gonçalves da Silva, argumentou que possuía terras na mesma localidade do requerente da carta apresentada anteriormente, de Bartolomeu Pereira Dantas, as quais teriam sido compradas do capitão-mor Francisco de Oliveira Ledo, há mais de quatro anos, recebendo uma escritura da venda. Timóteo Gonçalves da Silva argumentou que as terras eram de posse imemorial do tal capitão-mor, desde os seus antepassados, e que Bartolomeu Pereira Dantas havia agido maliciosamente ao requerer tais terras. ${ }^{42}$

Bartolomeu Pereira Dantas alegou que as terras eram consideradas da Casa da Torre, e Timóteo Gonçalves da Silva alegou que eram dos antepassados dos Oliveira Ledo, reforçando a ligação entre tais famílias, na qual a última, como representante, administrava o "patrimônio" da primeira na capitania. Eram terras com áreas imensas, que por não serem

\footnotetext{
${ }^{37}$ Pode-se fazer um paralelo, com um caso específico de conflito entre a família dos Guedes de Brito e de moradores, no qual estes últimos acreditavam que as terras compradas ou arrendadas por eles aos Guedes de Brito eram terras legalizadas, mas ao serem informados da lei, passaram a justificar-se dizendo que eram os verdadeiros possuidores e cultivadores. Deve-se lembrar que o cultivo era um fator legitimador para a concessão da sesmaria. ALVEAL, Carmen, op. cit., p. 288.

${ }^{38}$ Provavelmente, alguma das três cartas registradas na Plataforma SILB, concedidas no ano de 1752, pelo governante Antônio Borges da Fonseca para o capitão-mor Francisco de Oliveira Ledo: Plataforma SILB PB 0407, PB 0408 ou PB 0409.

${ }^{39} \mathrm{Na}$ carta aparece o termo sub-repticiamente, que tem o significado de algo ilícito.

${ }^{40}$ Antônio Borges da Fonseca foi governador da capitania da Paraíba entre 1745-1753.

${ }^{41}$ CARTA de sesmaria doada a Bartolomeu Pereira Dantas, em 11 de fevereiro de 1760. Plataforma SILB PB 0525

${ }^{42}$ CARTA de sesmaria doada a Timóteo Gonçalves da Silva, em 17 de julho de 1761. Plataforma SILB — PB 0559.
} 
cultivadas totalmente, fazia com que pedaços de terras ficassem sem aproveitamento, levando outros a cultivarem-nos, como fez Bartolomeu Dantas, que, segundo ele, cultivou por mais de 30 anos, desde 1730, pelo menos. Em 1753, baseando-se no discurso das duas cartas citadas, o capitão-mor Francisco de Oliveira Ledo teria obtido uma data, conforme a lei, nas terras cultivadas por Bartolomeu Pereira Dantas, o que fez com que este último ficasse impossibilitado de cultivar. Demonstrando o conhecimento da lei, Bartolomeu Pereira Dantas alegou a seu favor, apelando para o princípio do cultivo como forma de concessão de sesmaria, o qual lhe foi concedida no ano de 1760. Entretanto, nestes setes anos (entre 1753 e 1760), o capitáo-mor, com a posse garantida na lei, ou mesmo no uso da violência, havia vendido as terras a Timóteo Gonçalves da Silva, que, por sua vez, sentindo-se ameaçado pela concessão realizada a Bartolomeu Pereira Dantas, em 1760, requereu para si o título de sesmaria, sugerindo ser mais seguro do que o título de venda. Amparado pelo próprio capitão-mor, que lhe havia vendido as terras e que intercedeu junto às autoridades, Timóteo Gonçalves da Silva conseguiu obter seu "justo" título. Mesmo com a escritura de venda em suas mãos, percebe-se a importância que o título de sesmaria representava. Entretanto, Bartolomeu Pereira Dantas, que alegou cultivar a terra há mais tempo, parece ter perdido a causa, talvez pela influência que Francisco de Oliveira Ledo possuía na Paraíba.

As acusaçóes contra a Casa da Torre recaíam, portanto, na falta do "justo" título, e os pontos utilizados a favor dos suplicantes eram que eles eram os reais cultivadores. Para entender, destarte, a concessão realizada a esses povoadores em detrimento dos poderosos da Casa da Torre, e as próprias justificativas utilizadas pelos requerentes nas cartas de sesmaria, é preciso entender o que era o sistema sesmarial e como se processou na América portuguesa.

O sesmarialismo, nas palavras de Costa Porto, permite entender a "história de nossa evoluçáo fundiária”. ${ }^{43}$ Este sistema teria sido implantado em Portugal, em 1375, por D. Fernando, a fim de promover o aproveitamento do solo, devido a uma crise de abastecimento que afetava Portugal. Costa Porto ressaltou que a legislaçáo de 1375 tinha a cultura do solo como obrigatória, tendo em vista o interesse coletivo de abastecimento. ${ }^{44}$ Transposto para o Brasil, o objetivo principal inicial do sistema de sesmarias era facilitar o povoamento em um território tão vasto e recém-descoberto, além da própria produção, que se iniciaria decorrente deste povoamento. Mais uma vez, entende-se o porquê das concessóes de extensas sesmarias nos dois primeiros séculos de colonizaçấo. Com a iniciativa de particulares, a Coroa concedia amplas regalias àqueles que se empenhassem na descoberta de novas terras, na conquista $\mathrm{e}$ no povoamento. Como afirmou Costa Porto, com poucas pessoas e muitas terras, não havia motivo para restringir o tamanho das datas de sesmarias. ${ }^{45}$

\footnotetext{
${ }^{43}$ PORTO, Costa, op. cit., p. 30.

${ }^{44}$ Ibid., p. 31-35.

45 Ibid., p. 58-60.
} 
Autores como Costa Porto (1965), Laura Beck Varela (2005), Carmen Alveal (2007) e Márcia Motta (2009) ressaltaram o caráter condicional do sistema sesmarial. Aqueles que recebiam sesmarias, denominados sesmeiros, na América portuguesa, diferentemente de Portugal, que correspondiam àqueles que fiscalizavam as sesmarias, recebiam terras e precisavam cumprir certas condiçôes, para que estas permanecessem em posse deles. Virgínia Rau, por exemplo, em relação à lei de sesmarias, ressaltou o seu caráter coercivo (RAU, 1982, p. 42) para aquele que recebesse a sesmaria a cultivasse. ${ }^{46} \mathrm{~A}$ terra era pertencente à Coroa, que poderia requerer para si terras já concedidas, caso não fossem cumpridas certas determinações, de acordo com a lei. Laura Beck Varela afirmou, por exemplo, em relação ao sistema sesmarial, que se tratava "de uma forma de apropriação, que aqui denominamos 'propriedade' não absoluta, condicionada por inúmeros deveres, e que se aproxima de uma concessão ou privilégio - por oposição ao direito de propriedade da doutrina jurídica liberal clássica" ${ }^{47}$ Essa apropriação amparava-se em uma das condiçôes consideradas essenciais no sistema de sesmarias, o cultivo. Solo inculto era motivo para que fosse concedida àqueles que tivessem vontade de aproveitá-lo, tornando-o útil.

Por ser um sistema condicional, esperava-se que certas cláusulas fossem cumpridas por parte daqueles que recebiam a sesmaria. O que se esperava, portanto, era que as cláusulas fossem cumpridas, o que tornava o sistema sesmarial, conforme já exposto, um sistema condicional. E quais seriam essas cláusulas? Costa Porto apresentou as seguintes: tornar a sesmaria produtiva no prazo de cinco anos; registrar nos livros da Provedoria; e nos últimos anos do século XVII foi estabelecida a obrigatoriedade de pedir confirmação régia. ${ }^{48}$ Em relação ao número de confirmaçóes régias efetivadas, observa-se que, comparado ao número de concessōes de sesmarias realizadas em território da América portuguesa, foi ínfimo, resultando em uma grande parte de sesmarias que não atendiam às cláusulas do sistema de sesmarias. ${ }^{49}$

Todas essas exigências foram sendo elaboradas ao longo do tempo, com a experiência do sistema sesmarial na colônia. Nos dois primeiros séculos de administração portuguesa na América, observa-se certa liberalidade em relação à concessão de sesmarias. Na última década do século XVII, ordens régias complementares às Ordenaçôes do Reino começaram a restringir seriamente o acesso à terra na colônia, afetando os grandes senhores de terras. Náo havia uma legislação específica quanto à dimensão das sesmarias, visto que o texto das Ordenaçôes Filipinas era genérico em relação ao assunto, sendo dadas terras que estivessem ao alcance do sesmeiro aproveitá-las. Uma legislação mais específica surgiu apenas em finais da década de 1690; assim como a obrigatoriedade da confirmaçáo régia para as sesmarias concedidas na América portuguesa, e a introdução do foro sobre as sesmarias doadas. ${ }^{50}$

\footnotetext{
${ }^{46}$ RAU, Virgínia. Sesmarias medievais portuguesas. 2. ed. Lisboa: Presença, 1982.

${ }^{47}$ VARELA, Laura Beck. Das sesmarias à propriedade moderna: Um estudo de História do Direito Brasileiro. Rio de Janeiro: Renovar, 2005. p. 86.

${ }^{48}$ PORTO, Costa, op. cit., p. 62.

${ }^{49}$ ALVEAL, Carmen, op. cit.

${ }^{50}$ Ibid., p. 276-277.
} 
Adentrando o século XVIII, as restriçóes continuaram, demonstrando diversas situaçóes conflituosas, reflexo dos conflitos entre grandes senhores de terras e os cultivadores efetivamente do solo. Conforme já citado, a Casa da Torre possuía um patrimônio enorme, além de poder e influência..$^{51}$ Moniz Bandeira, baseado nas anotaçôes do padre João Antônio Andreoni em Cultura e opulência do Brasil, argumentou que o sertão da Bahia, embora tivesse uma dimensão territorial extensa, pertencia "quase todo a duas das principais famílias da mesma cidade, que são a da Torre e a do defunto mestre-de-campo Antônio Guedes de Brito". ${ }^{52}$ Segundo Pedro Calmon, a regiáo do Piauí permanecera despovoada e desconhecida ${ }^{53}$ até meados do século XVII. O seu devassamento teria ocorrido pela pecuária, vinda da Bahia, com sertanistas como Domingos Jorge Velho, os irmãos Sertão, Garcia d’Ávila da Casa da Torre, e os Guedes de Brito. Quando conquistavam as terras, pediam sesmarias infinitas, possuindo muitas léguas. ${ }^{54}$ Além das já citadas terras na capitania da Paraíba, vistas nas cartas de concessão de sesmaria deste artigo, a mesma Casa da Torre dominava "uma extensão de 260 léguas de testada na capitania de Pernambuco, à margem do rio Sáo Francisco, entre o qual e o Parnaíba apossou-se de mais de 80 léguas". ${ }^{55}$ Ao tratar das sesmarias gigantes, nas quais algumas estavam com terras ainda a descobrir, Ângelo Pessoa argumentou que tal atitude tinha o objetivo de "apropriar-se, previamente, por via jurídica, dos potenciais recursos existentes em uma determinada região". ${ }^{56}$ Entâo, com a liberalidade dos dois primeiros séculos na América portuguesa, a Casa da Torre obteve suas extensas sesmarias. Essas sesmarias, que tinham limites imprecisos, davam margem à Casa da Torre de arrogar para si o direito de infinitas terras. Percorrendo o rio São Francisco, instalando fazendas, mantendo alianças com famílias poderosas, exigindo foros ou rendas àqueles que se instalassem em terras ditas suas, não tardou para que os conflitos com aqueles que não aceitavam essa opressão viessem à tona. Aliás, era mesmo interesse da Coroa limitar esse poder, demonstrada na posição do Conselho Ultramarino nos conflitos que se seguiram no século XVIII.

Mais uma vez, João da Maia da Gama, ferrenho opositor da Casa da Torre, em suas anotaçôes de viagem, registrou a sua indignação contra esta família. Ao escrever sobre as sesmarias concedidas nos séculos XVI e XVII, o governante registrou o seguinte:

Gracia de Avilla [...] da Caza da Torre que tendo no tempo dos Fillipes huã conceção de 50 legoas de terra e não se asentando ainda hoje com serteza qual seja a dita cerra principio desta

\footnotetext{
${ }^{51}$ Patrimônio entendido na perspectiva de PESSOA, Ângelo Emílio da Silva, op. cit., p. 153-154.

52 BANDEIRA, Moniz, op. cit., p. 236.

${ }^{53}$ Atentar que esta afirmação despovoada representa a falta da presença de ocupação portuguesa, pois indígenas lá existiam.

${ }^{54}$ CALMON, Pedro, op. cit., p. 87.

${ }^{55}$ BANDEIRA, Moniz, op. cit., p. 236. Na Plataforma SILB há o registro de seis extensas sesmarias concedidas pelo governo de Pernambuco a Francisco Dias D’Ávila, entre 1681 e 1684. Plataforma SILB - PE 0353, PE 0375, PE 0377, PE 0379, PE 0380 e PE 0381.

${ }^{56}$ PESSOA, Ângelo Emílio da Silva, op. cit., p. 118.
} 
data, e não tendo nunca havido medição destas terras, sequer, Gracia de Avilla com esta data e com outra que ouve de 20 legoas se hir senhorear de todos os certóes por mais de trezentas legoas porque quer ser S. das terras do certao da Par. ${ }^{a}$, nos careris, Pinhançô e Peranhos e Rio do Peixe, e quer ser $S$. das terras de Jaguaribe aonde entre elle, ou seus collonos, e Procuradores e athe gados. ${ }^{57}$

Neste pequeno trecho, observa-se a imprecisão do tamanho das sesmarias concedidas, o que fazia com que famílias poderosas arrogassem para si o domínio de terras além do que podiam cultivar ou do que, na verdade, estavam na extensão das sesmarias concedidas. Com um maior centralismo da Coroa e uma maior determinação de leis no tocante ao sistema sesmarial, entretanto, começaram a ser impostas novas exigências que se mostraram inviáveis para aqueles que possuíam extensas terras, como a demarcação, medição e o aproveitamento efetivo da área da sesmaria. Evidentemente, outras pessoas desbravavam terras que "pertenciam" a esses grandes senhores e que nem haviam sido descobertas, e cultivavam-nas. Isto pode ser percebido, novamente, nas palavras de João da Maia da Gama:

e estando todos estas terras povoadas de gentio, e não penetradas nem povoadas, e hindo vários descobridores com despesas de suas fazendas e com evidente prigo de vida morrendo muitos e matando-lhe o gentio e outros parentes e escravos descobrirão sítios, e povoaram-nos e defenderam-nos do gentio com perigo [...] e depoês de estabelecidos vinhão os Procuradores da Casa da Torre, e por forma, ou os fazião despejar, ou os faziam paçar escritos de arrendamento..$^{8}$

Não se deve descartar o uso da violência utilizada, como o próprio João da Maia da Gama relatou, por meio dos procuradores da Casa da Torre. Segundo o alferes Bartolomeu Pereira Dantas, já mencionado, ele afirmou que havia pagado rendas à Casa da Torre, mas que as terras que solicitava por sesmaria não eram dela "por esta não ter titulo algum de sesmaria mais que uma intrusa posse" na ribeira do rio do Peixe. ${ }^{59}$ Segundo o dicionário de Raphael Bluteau, de 1728, intruso significa "que se metteo de [posse?] de hum officio, ou dignidade violentamente, \& por meyos illegitimos... Intruso por força, com violencia. Intruso com o favor, \& com a authoridade de alguem...”. Portanto, mais uma vez, observa-se o discurso da ilegalidade, o que demonstra o conhecimento da legislação de sesmarias por parte desses requerentes, e ainda há neste discurso o apontamento do uso da violência, da força, para possuir algo. ${ }^{60}$

\footnotetext{
${ }^{57}$ MARTINS, F. A. de Oliveira, op. cit., p. 25-26.

58 Ibid., p. 27.

${ }^{59}$ CARTA de sesmaria doada a Bartolomeu Pereira Dantas.

${ }^{60}$ BLUTEAU, Raphael. Brasiliana USP — Dicionário on-line Raphael Bluteau, Vocabulário Portuguez \& Latino. v. 4, 1728. p. 179. Acesso em: 19 mar. 2013. Disponível em: <http://www.brasiliana.usp.br/en/dicionario/>.
} 
O cultivo, como aproveitamento do solo, era requisito elementar no sistema sesmarial, e foi o fundamento que amparou esses cultivadores, encontrando seu apoio legal por meio da carta régia de 20 de outubro de 1753. Esta carta influenciou diretamente a venda de terras na capitania da Paraíba e possibilitou a concessão das sesmarias aos cultivadores. Visto um pouco o sistema sesmarial, e rapidamente como a Casa da Torre conquistou seu patrimônio e como o administrava, poder-se-á deter novamente nas 31 cartas de sesmarias, e tentar-se-á elucidar uma hipótese para este fenômeno que ocorreu no sertáo da capitania da Paraíba, relacionando-as com a carta régia de 1753.

\section{A carta régia de 20 de outubro de 1753: contrariando a Casa da Torre}

A carta régia de 20 de outubro de 1753, enviada por D. Jose a Luis Correa de Sá, governador de Pernambuco, surgiu como forma de solucionar problemas de posseiros e sesmeiros. Resultante de contendas e litígios entre herdeiros de Francisco Dias de Ávila, Francisco Barbosa Leam, Bernardo Pereira Gago, Domingos Afonso Sertao, Francisco de Sousa Fagundez, Antonio Guedes de Brito e Bernardo Vieira Ravasco contra moradores do Piauí, sertão da Bahia e Pernambuco, certamente, do fato de cultivadores e posseiros terem recusado-se a pagarem as rendas cobradas pelos herdeiros por meio de seus procuradores. Anteriormente, João da Maia da Gama, já atestava essa situação, e propunha uma solução:

Tão bem entendo e me paresse que de justiça deve V. Magestade mandar excluir a Gracia de Avilla todas as datas de terras o obrigallo merdisse e sitados... e povoadores mostrar os que por si povoou para que estivessem fora da sua medição e as que elle não povoou por si se deem de novo aos povoadores ${ }^{61}$.

João da Maia da Gama aconselhou ainda que a vossa majestade agradar-se-ia muito de 10 mil réis por ano de cada fazenda, os quais os moradores não negariam em oferecer, por se livrarem de continuadas violências cometidas pela Casa da Torre. Bandeira, quando citou Antonil, relatou que os senhores da Casa da Torre possuíam currais próprios e outros arrendados em sítio, geralmente de uma légua, no qual cobravam 10 mil réis de foro cada ano. ${ }^{62} \mathrm{~A}$ resoluçáo de 11 de abril e 02 de agosto de 1753, porém, decidiu anular todas as datas, ordens e sentenças da narrativa que culminaria na carta régia de 20 de outubro de $1753,{ }^{63}$ além de limitar a extensão das sesmarias em três léguas de comprimento por uma légua de largura, devendo haver uma separação de uma légua entre duas sesmarias, para todo o território. ${ }^{64}$

\footnotetext{
${ }^{61}$ MARTINS, F. A. de Oliveira, op. cit., p. 27.

${ }^{62}$ BANDEIRA. Moniz, op. cit., p., 236.

${ }^{63}$ Anulava apenas a partir daquelas datas, mas as 31 sesmarias foram solicitadas uns 15 anos antes.

${ }^{64}$ Ordens régias complementares - Plataforma SILB. In: AHU-PA, PA, cx. 165, doc.11754; AHU-PA, PA, cx. 75, doc. 6283; AHU-PA, PA, cx. 5, doc. 321.
} 
Segundo Costa Porto, a carta régia de 20 de outubro de 1753 criou a necessidade de uma reavaliação das sesmarias concedidas, e entendia que as terras haviam sido doadas para que fossem cultivadas e não para repartirem, ou arrendarem e aforarem. ${ }^{65}$ Para Costa Porto, depois de 1753, o posseiro obteve vantagem, pois a preferência era para quem efetivamente cultivava os sítios. ${ }^{66}$ Logo, o apoio ao posseiro contra o grande senhor de terras estava legalmente nas ordens régias complementares, desde fins do século XVII até a resolução de 1753 em diante. "Em tese, tudo perfeito: mas na prática, nenhuma esperança de que funcionasse, naquelas distâncias, o disciplinamento baixado", argumentou Costa Porto. ${ }^{67}$ Apesar dessa afirmação, o que se observa na capitania da Paraíba foi que o disciplinamento baixado resultou em efeito positivo para os cultivadores. Após 1753, o número de doaçôes de sesmarias na Paraíba em terras ditas pertencentes à Casa da Torre cresceu significativamente, conforme demonstrado no quadro 1. Entre 1757 e 1776, foram 31 sesmarias concedidas em favor dos posseiros, em detrimento do grande senhor de terras. Pode-se pensar, portanto, conforme argumentou Márcia Motta, que a provisão de 1753 teria sido "uma tentativa de intervir e controlar o processo de ocupação territorial e talvez tenha sido promulgada para solucionar os conflitos oriundos da dinâmica de formação do patrimônio da Casa da Torre". ${ }^{68}$ Os próprios requerentes das tais cartas de doação utilizavam os princípios contidos na ordem régia de 1753 nas justificativas para concessão das sesmarias, compreendendo a ilegitimidade das terras da Casa da Torre e, consequentemente, compreendendo a ilegalidade que eles mesmos estavam. Portanto, esses cultivadores requeriam as sesmarias, a fim de obter a terra na forma da lei. Isto se comprova, por exemplo, por meio de carta de sesmaria concedida em 6 de março de 1760, na qual o requerente doutor Manoel de Araujo de Carvalho, que era cônego da Catedral de Olinda,

...diz que como legitimo herdeiro de seus paes Coronel Manoel de Araujo Carvalho e D. Anna da Fonseca Gondim, possue a mais de 60 annos um sitio de crear gados, chamado Olho d'Agua, na ribeira do rio do Peixe, povoado por seu pae, e não obstante pagar foro á casa da Torre que se achava indevidamente senhora de todas as terras que outros descobriram e povoaram, e porque S. M. pela ordem de 20 de Outubro de 1753 annulou aquellas doaçóes e dominios que tinha a casa da Torre e outras, mandando dar por nova graça aos cultivadores... ${ }^{69}$

\footnotetext{
${ }^{65}$ PORTO, Costa, op. cit., p. 90.

${ }^{66}$ Ibid., p. 122.

${ }^{67}$ Ibid., p. 90.

${ }^{68}$ MOTTA, Márcia Maria Menendes. Direito à terra no Brasil: a gestação do conflito, 1795-1824. São Paulo: Alameda, 2009. p. 134.

${ }^{69}$ CARTA de sesmaria doada a Manoel de Araujo de Carvalho, em 6 de março de 1760. Plataforma SILB - PB 0528.
} 
Anteriormente, em 4 de novembro de 1756, Francisco de Oliveira Ledo, capitão-mor do Piancó, pedia ao Conselho Ultramarino que a ordem de 1753 contra os Ávila, que queriam ser senhores de infinitas terras, fosse executada, a fim de que fossem resolvidas as injustiças que sofriam os povoadores. ${ }^{70}$ Observando o nome da pessoa que fez o requerimento (Francisco de Oliveira Ledo) e o conflito resultante entre ele e os membros da Casa da Torre, uma pergunta é formulada: e a relação entre os Oliveira Ledo e os Ávila? O tempo pode ser a resposta para essa questáo. A possível aliança, com Teodósio de Oliveira Ledo, como procurador da Casa da Torre na capitania da Paraíba, em fins do século XVII e início do século XVIII, não teria mais sido reafirmada na geração seguinte, com seus descendentes, na segunda metade do século XVIII. Uma informação interessante apresenta-se no livro O feudo, de Moniz Bandeira, sobre a Casa da Torre: "As terras da Casa da Torre situadas naqueles sertôes táo distantes de Tatuapara estavam naturalmente entregues ao mando e desmando de procuradores, homens rudes e violentos que pouco a pouco assumiram, de fato, o seu senhorio". ${ }^{71}$ Moniz continuou argumentando que os procuradores agiam por conta própria, e não necessitavam de ordens dos senhores da Torre, assim, a família de Teodósio de Oliveira Ledo teria passado a ocupar $2 / 3$ do agreste e da parte ocidental do Cariri. ${ }^{72}$

A Casa da Torre não ficou passiva diante de tais atos que a prejudicavam diretamente. D. Inácia de Araújo Pereira e seu neto, Garcia d'Ávila Pereira de Aragão, pediram que não tivessem efeito as concessóes realizadas pelo governador da Paraíba em terras já povoadas e possuídas pela Casa da Torre, ${ }^{73}$ resultando na carta régia de 26 de setembro de $1757,{ }^{74}$ na qual D. José ordenou que fossem revogadas as sesmarias concedidas pelo governador da $\mathrm{Pa}-$ raíba em terras que fossem, por "justo" título, de D. Inácia de Araujo Pereira. Apesar disto, nos anos seguintes, conforme demonstrado, as concessōes na capitania da Paraíba em terras pertencentes à Casa da Torre, na verdade, intensificaram-se entre 1757 a 1776, reconhecendo os requerentes que a Casa da Torre não possuía título das terras.

Segundo a petição realizada pelos Ávila em 1757, em finais dos anos de 1756, o governador da Paraíba, Luís Antônio de Lemos Brito, por meio de editais, ordenou que quem possuísse terras nos sertôes do Piancó e rio do Peixe teria o prazo de três meses para solicitar a concessáo da sesmaria, com o risco de que elas poderiam ser concedidas a quem as pedisse. Portanto, isto justifica também, conforme mostrado no quadro 1 , o porquê de que entre 1757 e 1776 foram concedidas pelo menos 31 sesmarias em terras supostamente pertencentes à Casa da Torre. Somente no ano de 1759 concederam-se 12 sesmarias nesta situação, mostrando que apesar do requerimento de Inácia de Araújo Pereira e seu neto, Garcia d'Ávila Pereira de Aragão, em 1757, as concessôes de terras da Casa da Torre foram inevitáveis.

\footnotetext{
${ }^{70}$ AHU-PB, PA, cx. 19, doc. 1507.

${ }^{71}$ BANDEIRA, Moniz, op. cit., p. 328.

${ }^{72}$ Para maior compreensão, ver COSTA, Renata Assunção da, op. cit.

${ }^{73}$ AHU-BA, PA, cx. 140, doc. 44.

${ }^{74}$ Ver Ordens Régias Complementares — Plataforma SILB.
} 
Com o requerimento enviado por Inácia de Araújo Pereira, no ano de 1757, o rei D. José solicitou o parecer do governador de Pernambuco, por provisão de 26 de setembro de 1757, respondida em carta no dia 16 de fevereiro de 1759 por Luís Diogo Lobo da Silva ao próprio rei. O governador de Pernambuco informou que, para atender a ordem do rei, fora preciso procurar notícias a respeito do assunto que envolvia a disputa de terras em questão na provedoria da Paraíba. Entretanto, o governador foi informado por resposta do sargento-mor governador interino, do provedor, do procurador, e do escrivão, todos da capitania da Paraíba, que não havia registro que indicasse posse dos senhores da Casa da Torre naquela região ou “jus adquirido sobre as ditas terras". Luís Diogo Lobo da Silva, todavia, ressaltou que os senhores da Casa da Torre apresentavam uma certidão, na qual constava que André Vidal de Negreiros, que havia sido governador da capitania de Pernambuco, havia passado, em 22 de julho de 1658, sesmarias ao capitáo Francisco Dias de Ávila e Bernardo Pereira, que, por sua vez, haviam estabelecido-se acima do rio São Francisco, indo das regiôes povoadas até a última aldeia do gentio Moipura, e para a parte do norte até a Serra do Araripe. ${ }^{75}$ Portanto, uma área extensa, e sem limites precisos. Luís Diogo Lobo da Silva ainda informou que essa sesmaria não havia sido confirmada pelo rei, e que a mesma era entendida pelos senhores da Casa da Torre de acordo com as localidades referenciadas na carta concedida por André Vidal de Negreiros, sendo, consequentemente, o fundamento deles para persuadirem a posse de uma terra tão extensa. ${ }^{76} \mathrm{O}$ parecer do governador de Pernambuco era de que a data concedida foi realizada "contra a forma de direito e ordens de Vossa Magestade".

Apesar do parecer do governador de Pernambuco, que apresentava em seus argumentos ser contrário à manutenção dessa extensa sesmaria de terra, em 18 de janeiro de 1760, consta uma consulta do Conselho Ultramarino, referente à capitania da Bahia, na qual foi ordenado por este mesmo órgão que as sesmarias concedidas pelo governador da Paraíba nas terras dos Ávilas fossem revogadas. ${ }^{77}$ No jogo de relaçóes estabelecidas entre os diversos agentes na colônia e no Reino, a influente família Ávila pode ter trabalhado para que o parecer do rei fosse favorável para si.

Novamente, contudo, acredita-se que este documento não surtiu nenhum efeito sobre as concessóes que continuaram ocorrendo em terras do sertão da capitania da Paraíba. Embora se possa pensar que tais terras, por serem em sua maioria vendidas aos cultivadores, pudessem não corresponder àquelas que a D. Inácia de Araújo Pereira pedia a revogação de sesmarias concedidas pelo governador da Paraíba, entende-se que as cartas aqui trabalhadas correspondessem realmente às tais reclamadas pela herdeira da Casa da Torre. Esta suposição baseia-se no período próximo entre as concessôes das 31 sesmarias (1757-1776), e do requerimento de revogação de D. Inácia de Araújo Pereira e do parecer do Conselho Ultra-

\footnotetext{
${ }^{75}$ AHU-Pernambuco, Papéis Avulsos, cx. 88, Doc. 7174.

${ }^{76}$ AHU-Pernambuco, Papéis Avulsos, cx. 88, Doc. 7174.

${ }_{77}$ AHU-Baía, cx. 143, Doc. 11005.
} 
marino (1757 e 1760); além da análise das cartas de sesmarias disponíveis em Lyra Tavares, que apresentam um considerável número de cartas de concessão na capitania da Paraíba. ${ }^{78}$ O que se verificou foi que a Casa da Torre perdeu aos poucos seu domínio sobre as terras da capitania da Paraíba, e, inclusive, em outras capitanias. ${ }^{79}$ Em fins do século XVIII e início do século XIX, a influência da Casa da Torre continuaria grande, embora concentrada na capitania da Bahia. ${ }^{80}$

Esse movimento de concessóes comprova-se também por meio da alegação feita pelo requerente Francisco de Santa Cruz de Jesus, que recebeu uma sesmaria no ano de 1764. $\mathrm{O}$ requerente afirmou que possuía um sítio na ribeira do Piancó, o qual havia comprado da Casa, "e porque ouve dizer que as muitas terras que a mesma casa possui se julgão devolutas, por não haver tirado data dellas", pretendendo o mesmo suplicante obter com “justo" título o tal sítio por sesmaria. ${ }^{81}$ Os suplicantes teriam utilizado a ordem régia de 20 de outubro de 1753 para requerer o título de sesmaria, garantindo a sua posse na forma da lei. A simples escritura de venda recebida da Casa da Torre não seria suficiente para que estes cultivadores se sentissem seguros, e a clara tendência da Coroa em apoiá-los possibilitou que estes legalizassem o seu domínio sobre as terras que haviam ocupado e cultivado.

\section{Considerações finais}

Com tudo que foi até aqui observado, questiona-se o porquê de a Casa da Torre ter vendido tais terras, e, quando para aqueles que ela vendeu as terras solicitavam uma sesmaria, por que a mesma Casa requereu a anulação das concessóes, se ela mesma as tinha vendido?

Segundo Moniz Bandeira "todo o gado nas Minas Gerais, antes da abertura em 1727 do caminho para o Rio Grande de São Pedro, no sul da América portuguesa, provinha dos campos do Piauí, bem como da Paraíba, de onde percorriam uma distância de 400 léguas até os centros de consumo". ${ }^{22}$ Sabe-se que a base fundamental da economia da Casa da Torre era a pecuária, possuindo currais nas ribeiras dos sertóes, exploradas, principalmente, pelos foreiros ou arrendatários, cobrando, geralmente, a razão de uma légua 10 mil réis por ano. ${ }^{83}$ Para Ângelo Pessoa, poder-se-ia pensar na participação dos Ávila no comércio de carnes (ver-

\footnotetext{
78 TAVARES, Joao de Lyra. Apontamentos para a Historia Territorial da Parahyba. 2. ed. Mossoró: Escola Superior de Agricultura de Mossoró, 1989.

${ }^{79}$ BANDEIRA, Moniz, op. cit., p. 415.

${ }^{80}$ Ibid., p. 416.

${ }^{81}$ CARTA de sesmaria doada a Francisco de Santa Cruz de Jesus, em 31 de julho de 1764. Plataforma SILB - PB 0614.

${ }^{82}$ BANDEIRA, Moniz, op. cit., p. 241. Baseia-se em CALMON, Pedro. História social do Brasil. t. I, 4. ed. São Paulo: Companhia Editora Nacional, Coleção Brasiliana, s/d. p. 172.; PRADO JÚNIOR, Caio. História econômica do Brasil. 17. ed. São Paulo: Brasiliense, 1974. p. 66.

${ }^{83}$ BANDEIRA, Moniz, op. cit., p. 241.
} 
des e secas), desde a etapa da criação, passando pelo transporte das boiadas e revenda na feira de Capuame e outras feiras, na Bahia, até o abate e venda em açougues ao público, em Salvador; criando, assim, uma rede tentacular que envolvia boa parte das capitanias. ${ }^{84}$ Portanto, a superação da pecuária do Rio Grande do Sul, durante a segunda metade do século XVIII, em detrimento da pecuária desenvolvida no sertão nordestino pode ser uma das chaves para a explicação do porquê tais terras terem sido vendidas ao longo do século XVIII. ${ }^{85}$

Outro fator decisivo que modificou a configuração do patrimônio da Casa da Torre foi a uniâo dos Ávila com os Pires de Carvalho. Com esta união, o morgado da Casa da Torre uniu-se a outra família rica e poderosa ${ }^{86} \mathrm{e}$ pode ter redirecionado o foco para os interesses dos membros da Casa da Torre, talvez até mesmo devido ao fato de a pecuária desenvolvida na região estar perdendo espaço para a sulista. Portanto, percebendo isto, os membros da Casa da Torre, talvez, foram desfazendo-se das suas terras, por meio de vendas. Segundo Calmon, Francisco Dias d'Ávila 3o "possuía engenhos de açúcar e duas fábricas de farinha". ${ }^{87}$ Já Ângelo Pessoa relatou que a Casa da Torre fazia outros negócios, envolvendo-se decisivamente com a produção do açúcar em fins do século XVIII, quando a pecuária do norte foi superada pela do sul no início do século XIX, e quando ocorreu a passagem do morgado da Casa da Torre para o controle dos Pires de Carvalho. ${ }^{88}$

Aliado a tudo isto, aponta-se a causa que se considera principal para a perda das terras da Casa da Torre na capitania da Paraíba: o próprio sistema sesmarial, com suas mudanças, decorrentes de um maior centralismo da Coroa portuguesa durante o século XVIII. Segundo Márcia Motta, "o esforço de disciplinar a ocupação, presente no estabelecimento de um limite máximo de concessão revela o reconhecimento de uma história pretérita de ocupação 'sem limites'" ${ }^{89}$ Conforme visto, o sistema sesmarial foi tornando-se complexo e restritivo por parte da Coroa, por meios das diversas ordens régias expedidas por ela ao longo dos anos do período colonial. Imposições mais limitativas vistas em fins do século XVII foram expedidas, e possibilitaram, como a ordem régia de 20 de outubro de 1753, por meio do princípio do cultivo, assegurar aos cultivadores diretos da terra a sua posse sobre ela. Talvez, percebendo que perderiam tais terras, visto a impossibilidade de cumprir todas as exigências que foram sendo impostas pela Coroa, em territórios tão extensos, e com todo o amparo dado aos cultivadores da terra, a Casa da Torre vendeu suas terras, conseguindo obter alguma vantagem sobre estas vendas, pois o sistema de sesmarias não proibia a venda, arrendamento ou aforamento de terras concedidas em sesmarias. Entretanto, o aumento de

\footnotetext{
${ }^{84}$ PESSOA, Ângelo Emílio da Silva, op. cit., p. 158.

${ }^{85}$ Ibid., p. 180.

${ }^{86}$ BANDEIRA, Moniz, op. cit., p. 329-336.

${ }^{87}$ CALMON, Pedro, op. cit., p. 159. Baseia-se em Doc. In: BORGES DE BARROS, Francisco. Bandeirantes e sertanistas baianos, p. 110.

${ }^{88}$ PESSOA, Ângelo Emílio da Silva, op. cit., p. 180.

${ }^{89}$ MOTTA, Márcia Maria Menendes, op. cit., 134-135.
} 
A LEGITIMIDADE DA GRAÇA: OS IMPACTOS DA TENTATIVA DE REFORÇO DA POLÍTICA SESMARIAL SOBRE AS TERRAS DA CASA DA TORRe na CAPITANIA Da PARAÍba (sÉCUlo XVIII)

Carmen Margarida Oliveira Alveal e Kleyson Bruno Chaves Barbosa

denúncias contra essas práticas, que feriam a noção de cultivo como legitimador da posse da terra, fez com que a Coroa revisasse sua posiçáo. Por conseguinte, aqueles que possuíam apenas a escritura de venda solicitaram o título de sesmaria das terras ocupadas, para assim, estarem legalizados com as novas ordens régias, e, portanto, ficarem mais seguros.

\section{Referências bibliográficas}

ALVEAL, Carmen Margarida Oliveira. Converting land into property in the Portuguese Atlantic World, 16 $6^{\text {th }}$-18 $8^{\text {th }}$ century. 2007. 366 f. Dissertação (Doutorado em Filosofia) - Johns Hopkins University, Baltimore, 2007.

BANDEIRA, Luiz Alberto Moniz. O feudo - A Casa da Torre de Garcia d'Ávila: da conquista dos sertóes à independência do Brasil. 2. ed. revista e ampliada. cap. VI. Rio de Janeiro: Civilização Brasileira, 2007.

BLUTEAU, Raphael. Brasiliana USP - Dicionário on-line Raphael Bluteau. Vocabulário Portuguez \& Latino. v. 4, 1728. p. 179. Acesso em: 19 mar. 2013. Disponível em: <http:// www.brasiliana.usp.br/en/dicionario/>.

CALMON, Pedro. História social do Brasil. t. I, 4. ed. São Paulo: Companhia Editora Nacional, Coleção Brasiliana, s/d.

. Os Procuradores. In: História da Casa da Torre - Uma dinastia de pioneiros. 2. ed. aumentada. cap. VIII. Rio de Janeiro: Livraria José Olympio Editora, 1958.

CEBALLOS, Rodrigo. Veredas sertanejas da Parahiba do Norte: a formação das redes sociais, políticas e econômicas no arraial de Piranhas (século XVIII). Anais do XXVI Simpósio Nacional de História — ANPUH, São Paulo, julho 2011.

CEBALLOS, Rodrigo; LÔBO, Isamarc Gonçalves. Procuraçôes, líbelos e escrivães - fontes manuscritas setecentistas do sertão paraibano. Cajazeiras: EDUFCG, 2012. CD-ROM.

COSTA, F. A. Pereira da. Chronologia histórica do Estado do Piaui. 1. ed. Recife: Typographia do Jornal do Recife, 1909.

COSTA, Renata Assunção da. Uma nova conquista: A família Oliveira Ledo e o processo de ocupação espacial do sertão do Piancó (1663-1730). Monografia (Graduação em História) - Departamento de História, Universidade Federal do Rio Grande do Norte, Natal, 2012. GROSSI, Paolo. A propriedade e as propriedades na oficina do historiador. In: História da propriedade e outros ensaios. Rio de Janeiro: Renovar, 2006

MARIZ, Celso. Expansão territorial — I Primeiras aldeias mestiças - Os paulistas e baianos no interior. In: MARIZ, Celso. Apanhados Históricos da Paraíba. 2. ed. João Pessoa: Editora Universitária UFPB, 1980. 
MARTINS, F. A. de Oliveira. Um herói esquecido: João da Maia da Gama. Vol. II. Lisboa: Coleção Pelo Império, 1944.

MOREIRA, Emília de Rodat Fernandes. Processo de ocupação do espaço agrário paraibano. Textos UFPB/ NDIHR no 24 set./1990.

MOTTA, Márcia Maria Menendes. Direito à terra no Brasil: a gestação do conflito, 17951824. São Paulo: Alameda, 2009.

. Tierra, Poder y Privilegio. Los mayorazgos coloniales y el ejemplo de la Casa da Torre (siglo XVIII). In: ÁLVAREZ, Maria José Pérez; GARCÍA, Alfredo Martín (Org.). Campos y campesinos en la España Moderna. 1. ed., v. 1. León: Fundación Espanóla de História Moderna, 2012.

PESSOA, Ângelo Emílio da Silva. As ruinas da tradição: a Casa da Torre de Garcia D'Ávila — família e propriedade no Nordeste colonial. Tese (Doutorado em História) — Faculdade de Filosofia, Letras e Ciências Humanas, Universidade de São Paulo, São Paulo, 2003.

PINTO, Irineu Ferreira. Datas e notas para a História da Paraíba. v. 1. João Pessoa: Editora Universitária, UFPB, 1977.

PORTO, Costa. Estudo sobre o sistema sesmarial. Recife: Imprensa Universitária, 1965.

PRADO JÚNIOR, Caio. História econômica do Brasil. 17. ed. São Paulo: Brasiliense, 1974.

RAU, Virgínia. Sesmarias medievais portuguesas. 2. ed. Lisboa: Presença, 1982.

TAVARES, Joao de Lyra. Apontamentos para a Historia Territorial da Parahyba. 2. ed. Mossoró: Escola Superior de Agricultura de Mossoró, 1989.

VARELA, Laura Beck. Das sesmarias à propriedade moderna: Um estudo de História do Direito Brasileiro. Rio de Janeiro: Renovar, 2005. 